\title{
REGARDING THE CULTURE OF MULTI-ETHNICITY AND COHABITATION IN THE WESTERN BALKANS...
}

\section{Sibel Akova ${ }^{1}$ Cenk Demirkiran}

İzocam Tic.ve San. A.Ş., İzocam Yalıtım Eğitim Merkezi

Received: 25.03.2013

Accepted: 09.04.2013
Original scientific paper

\section{THE TV SERIES "FAREWELL TO RUMELIA"}

The media, an inseparable part of daily life, influences the thoughts, behaviour and attitudes of millions of people through the transmission of cultural images such as music, themes and visuals, has succeeded in reaching the masses with an attractive form of presentation and in a sense, has incorporates - almost immediately in the world of today - universal truths and developments into the lives of individuals with pictures and sounds, reporting on events and people, allowing individuals to internalise the images presented and has become a point of reference in social life. Together with the development of modern technology, media of mass communication and in extension, media channels, have transcended national and cultural boundaries to reach the masses.

Developing in the second half of the 20th century, the television, as one of the most effective mass communication media of the modern age, has combined sound and images to create a technical medium where culture is produced, transmitted, circulated and consumed and subsequently recycled to reach the target audiences, while in terms of the transmission of messages, the television has become the flagship of the media economy in comparison with other mass communication media and channels.

As the influences of globalisation have been felt upon the creative processes of film and serial in- struments and in the adoption and dissemination of strategic objectives, global cultural transmission is more varied, wider in scope and with more intense content than ever before. Furthermore, as a result of the constant development, regeneration and transformation of communication technology, we can postulate that television serial and film scenarios are a new form of marketing communication, as they are deeply intertwined with daily life and culture in the modern world. However, mass communication media gather groups of people with a common language and interest, causing groups to become communities. The role of mass communication media in forming communities with common characteristics and interests has developed in parallel with the development of mass communication media. These communication media have negated geographical boundaries, forming common ground for social relationships, while the importance of communication media has increased as the media reaches more isolated communities, constantly increasing the size of the masses. The experience of the world as cultural cosmopolitanism and the globalisation of the media through the simulation of metaphorical images in relation to the globalisation of communication has led to the internalisation of feelings of globalisation by individuals under the influence of the media, forming the basis for a social and industrial discourse.
${ }^{1}$ Correspodence to:

Sibel Akova, Çalışma Y. Ekonomisti, İzocam Tic.ve San. A.Ş. Teknik Pazarlama Müdürlüğü, İzocam Yalıtım Eğitim Merkezi Phone: (0262) 75481 71-72 / 0530-469 2082

E-mail: akova@izocam.com.tr 
As the modern and consumption based communities of today consist of signs, images and ideas, the television has a significant role in stimulating desire through hypnotic and simulated scenarios and hybrid message media.

From this argument; we will examine the series "Farewell to Rumelia", set in Ottoman Macedonia and telling the story of a poor milk seller and family man (Sütçü Ramiz) and the trials and tribulations of his family, in order to understand how ethnic ideologies are approached and reproduced through television series. The Balkans, with a history of religious, language and ethnic pluralism, was the scene for a multitude of historical conflicts, civil wars and an environment of inconsistency, but also where a culture of community life flourished; this culture of coexistence, considered to be a social laboratory, is now a popular area of study for researchers and academics interested in the areas of intercultural communication, ethnicity and multiculturalism. The series "Farewell to Rumelia" is an important work of fiction in the context of Turkey and the Balkans, allowing us to examine the social, political and cultural reflections of our recent past. This study aims to examine the Turkish and Balkan cultures in the context of multiculturalism, in order to analyse the culture of coexistence in the framework of various theories, arguments, approaches and concepts.

Keywords: West Balkans, Globalisation, Ethnicity, Culture, Farewell to Rumelia.

\section{THE BALKANS; AND ETHNIC LABORATO- RY}

The Balkans have a history as ancient as the Mediterranean region. The first instance of unitarianism in the Balkans as a political and cultural structure occurred in Roman times. In Latin, the region was referred to as Hacmus (Otoyol, 1999, p. 1) In the historical context, we can see that the Balkans were associated with a number of different concepts and named accordingly. The peninsula, one of the three major peninsula of Europe, has been known by a number of different names since antiquity, on occasion being referred to as the Balkans before the emergence of the Turks in history, after which the Balkans became the most frequently used name for the region. The Balkans have an important geostrategic location, being the main land route from Asia into Europe and acting as the gatekeeper. According to Bozidar Jezernik, the Balkan Peninsula remained yet unnamed until the beginning of the 19th century. In 1808, German geographer August Zeune named the region the Haemus peninsula. In the English language, the name "Great Balkan" was used instead of Haemus for the first time in 1767, by Frederick Calvert (Jezernik, 2006, p. 1) The Balkans are also known as Slovogreece, the Greek peninsula (Halbinsel Griechenland) and the South-East European peninsula (Südosteuropäische Halbinsel) (Davutoğlu, 2001, p. 121). In modern literature, we see that American and European writers and academics prefer to use the term "Southeast Europe" instead of the Balkans. However, in recent years, the former Yugoslav Socialist Republic (the region including the former Yugoslavian countries of Bosnia and Herzegovina, Croatia, Macedonia and the Federal Republic of Yugoslavia (Serbia and Montenegro) and Albania) have been referred to as the West Balkans in EU sources (Kavalal1, 2005, p. 37). The scope and context of this study is limited with the West Balkans and the term West Balkans will be used. The Balkan region may also be referred to as Byzantine Europe, Ottoman Europe, South - Mid - Southeast Europe or the Near East in various studies and research. In Ottoman Imperial nomenclature, the Balkan region was referred to as Rumeli (Rumelia), Rumeli-i Şahane (Imperial Rumelia) or Avrupa-i Osmani (Ottoman Europe). Up until the 19th Century, the Balkans were descrived as European Turkey by the Europeans, both in the literature and history of the time. The nomenclature used varied in the historical process, according to the changing conjuncture and between European and other states. The Balkans represented different perceptions and constructs for different nations and was named accordingly; the "chains of the world" by the Italians, barbarism for the French and chaos for the Germans and the region was even the setting for murder in Agatha Christie novels. 
Allthough there is no clear definition as to which countries the Balkan region includes (Palairet, 2000, p. 1); The Balkans or the Balkan Peninsula is understood to be the furthest Eastward of the three great peninsula of Southern Europe. The Balkan Peninsula is surrounded by the Mediterranean Sea in the South, the Adriatic Sea in the West, the Black Sea and Aegean Sea in the East. Although there is no consensus on the borders of the region, there are different views on where the Northern border of the Balkan Peninsula lies and which countries can be counted as Balkan countries. In general, the system formed by the rivers Danube, Sava and Kupa are accepted to be the Northern border of the peninsula (Jelavich, 2006, p. 1). To identify the borders of the Balkans is a similar challenge to identifying the borders of Europe. As the Balkans is home to valuable and fertile agricultural land, water sources and suitable habitable areas, similar to Mesopotamia and Egypt, and the favourable climate of the South and East coasts, the region has been conquered and held by large number of tribes, peoples, states and empires throughout history. In the geographical sense, the existence of a variety of highlands, tall mountains and mountain passes, leading to fertile valleys, the Balkans have been an important gateway and base between Asia, Europe and the Middle East. This has led to a long history of raids and invasions in the Balkans, inspiring the Italian name for the region, the chains of the world.

The geographical name comes from a word for a mountain range covered in dense forest and also the region has been home to one of the most significant examples of a culture of coexistence encompassing geographical divides, ethnic pluralism, multiculturalism, political and cultural differences. Furthermore, the region is significant in the world as a hotbed of nationalism. For these reasons, the Balkans have been described from time to time as a melting pot, a combination of peoples, a powder keg or a duelling ring. The Balkans also embody the classical discourse of the Museum of Civilisation. Although the Balkans are outside of and very different to our own country, starting from the Ottoman period, the region came under the influence of Turkish culture and spirit (Eker, 2006, p. 71). Indeed the Balkan region is a mosaic or sometimes an oil painting of intertwined cultural traditions, beliefs, customs and folkways, that has some difficulty in drawing its borders, seemingly a museum of ethnology where complexity rules. Ethnic groups have been defined more according to language or religion rather than nationality. Etnicity is less about biology and more about differences in lifestyle when compared to the rest of the community or the dominant group. Ethnicity is not racial, but cultural. As ethnicity is cultural, it encompasses all of the elements of the culture. Ethnicity cannot be defined only according to religion, language, tradition, convention or art; in short, all of these elements define ethnicity (Erkal, 2005, p. 134). Ethnicity is the collective identity of a group of people, based on the differences in language, race, religion, culture and lifestyle. This collective identity is indicative of a process rather than a situation and can evolve over time depending on the relationship between different groups (Buran, Çak, 2012, p. 26). Ethnicity may also be cultural proximity either felt or percieved towards a specific group or structure. In this context, ethnicity is a characteristic that is transmitted from generation to generation, inherited from the original culture, that is protected by individuals and groups sharing autonomous and distinct cultural traditions and who feel the need to conserve this identity. Ethnicity is a vital metaphor in the lives of individuals, holding the status as an identity such as other social, political, cultural or vocational identities.

Defining and clearly positioning the concept of ethnicity within the terminology is a difficult endeavour, as with many other concepts in the field of social science, creating many complex issues. The concepts of ethnic identity and ethnicity can be defined based on a number of philosophies, perceptions, patterns, criteria and parameters. The related definitions can be varied, used interchangeably by different parties, flexible or equally rigid. Basically, we can define groups that are distinct from others on the basis of language, religion, ancestry or a feeling of belonging to a culture in relation to ancestry, creating the perception that the group is a separate entity, with feelings of connectedness, solidarity, protection and belonging between the members, as ethnic groups. The word "etnos" comes from Greek, was used in Latin and then passed into English and French; from this point onwards, the concept became widely used, widening the scope and conceptual framework. The word has become a part of the literature and has been used up to the modern era. The concept has remained vital throughout history. Etnicity is less about biology and more about differences in lifestyle when compared to the rest of the community or the dominant group. Ethnicity is not racial, but cultural. As ethnicity is cultural, it encompasses all of the elements of the culture. Ethnicity cannot be defined only according to religion, language, tradition, convention or art; in short, all of these elements define ethnicity (Erkal, 2005, p. 134). 
Smith maintains that there is no other term that can fully express ethnic groups and communities in the context of the characteristics of the concept and multiplicity of meaning. The existence of ethnic groups is only possible with the sustanence of the delicate lines allowing us to distinguish between the groups and percieve their differences. Ethnicity is the collective identity of a group of people, based on the differences in language, race, religion, culture and lifestyle. This collective identity is indicative of a process rather than a situation and can evolve over time depending on the relationship between different groups (Buran, Çak, 2012, p. 26). In the past, many studies have been carried out and many theoretical approaches have been developed on ethnicity and ethnic groups. In the last fifty years, the number of ethnic studies have increased, while the sources, scopes and content of these studies have diversified. Denying that the phenomenon of globalisation and political, social and economic transformation has had an effect on this diversity would be futile. Indeed, the feeling of belonging to a group, region or structure absolutely provides individuals and groups with a shelter against the outside world. As in every area, structure and system from antiquity up to the modern age, with the influence of globalisation, ethnic ties and ethnic groups have given way to democratic understandings and philosophy, based on the principles of consent and voluntary participation. Due to the discourse of sharing a common culture, the concept of ethnicity develops awareness among individuals. With the development of communication technologies and the prevalence of widespread communication networks, existing interaction has increased, leading to an increase in popularity in the concepts of ethnicity and ethnic groups today. Ethnic identity is considered to be a social status and occupies a relatively significant position against of statuses and identities. Ethnic groups have an unlimited number of members, with the convening of members occurring on the basis of individual relationships, sharing a feeling of unity through a consistently equitable relationship model.

For five centuries, the Balkans were geographically almost completely under Turkish rule, allowing Turkish culture to be diffused in the Balkans and adopted by the Balkan peoples. The Balkan lands are populated by intertwined and interrelated peoples, marked by ethnic diversity and cultural richness. The Balkan panorama can be summarised best by looking at groups sharing culture, traditions, religion and ethnic identity but speaking different languages, or those speaking the same language and having the same ethnicity but belonging to different religions. After the breakup of Yugoslavia, the region is divided into 10 different political structures, home to more than 75 million people speaking 10 different languages and belonging to one of the three semitic religions (Özkürkçü, 1998, p. 10). Furthermore, we can say that the mountainous geography marked with valleys is a fine metaphor to describe the dividedness of the people. That the Balkan Peninsula has been easily accessed from different directions throughout history is an important factor in the complexity of the ethnic structure. Although many different languages are spoken in the Balkan region and there are many different political units and structures, there are communities who belong to each of the three monotheistic semitic religions. In the cultural and social sense, this has allowed groups to come toge0hter, develop relationships, build common cultural structure, adopt a culture of coexistence, create a joint communal awareness and learn and gain a sense of cohabitation. The religious structure has shaped the cultures of the communities living in the Balkans. Furthermore, we must not forget that religion has the power to influence to economic and political structures.

\section{THE EFFECTS OF MASS COMMUNICATION MEDIA ON CULTURAL TRANSFORMATION}

We know that mass media has permeated into every area of individual life today. In daily life today the absence of mass communication media is a major difficulty; one one hand individuals become dependent on communication metaphors and on the other, live their lives under a constant barrage of messages. Mass communication media have been classified and described in different conceptual frameworks by different researchers and academics. Individuals are exposed to an unlimited number of media arguments and consume many of these arguments presented through mass media as a ritual in their daily lives in order to distance themselves from the routine flow. As individuals derive pleasure from consumption, they internalise the messages, content and emotions presented in programmes by identifying the lifestyles and experiences recommended in consumption arguments with their own lives. In communication research before the 1940's, we see that there was a strong belief in the power of persuasion of mass communication media. 
In parallel with this belief, we can say that mass communication media does have the power to change people's beliefs, attitudes, perception patterns, preferences and inclinations. The mass communication media are reproduced, developed and strengthened every day, further influencing the lives, perceptions and subconscious of the target group, simultaneously all over the world.

As the national and international groups that are exposed to television programmes are larger than ever before, due to the development of technology, we see how successful the mass media is at gathering communities around a common language and common interest. Furthermore, we can also observe how strongly the concepts of media and culture are tied together in the context of grift relationships. The role of mass communication media in developing loyal and dependent communities has emerged in parallel with the development of mass communication media. Communication media are able to transcend even continental boundaries, reaching more and more geographical areas and larger groups. This has led to the emergence of unique and significant eventualities in the context the power of self determination of the individual. In the conjunction of today, communication technologies allow us to produce, receive and send common information easily and rapidly.

Mass communication media spread mass communication arguments such as radio, television and newspapers, accelerating the communication process. Through mass communication media, it is possible to learn about events unfolding all over the world. The development and spread of telecommunication and internet technologies facilitates the communication process, making the world a smaller place and negating boundaries. The issue of the pacification of the life of the individual under a constant bombardment through a variety of types and media from the mass communication media and the diminishing questioning capabiltiy of the individual has been brought up many times.

The most important mass communication media in the dissemination of cultural symbols is the television. Indeed, the television is the most effective among all the media as it can both show and tell; it is different from the other mass communication media as it can cover all kinds of messages. The television is the primary media allowing individuals to learn about the culture they live in. For this reason, the depiction of the television of the world forms a model for the correct depiction of the world (Postman, 1994, p. 96). The television also serves the function as a centralised, mass produced intellectual control mechanism. We can define the television as a centralised story teller aimed at the masses or society. For centuries, stories, legends, myths and other rituels belonging to a culture would be passed down by parents, teachers, community leaders or other leaders and holy men, face to face. Today, this function of these people is carried out by the television, which tells the most stories in the most time to the most people, spreading and generalising values. Another important function of the television is its role as an agent of socialisation. In the historical sense, the unique features of the television have overcome literacy as the main source of information for communities, taking over the role of creating common symbolic environments.

Mutlu explains the functions of the television on the basis of reflectiveness. According to Mutlu, reflectiveness is a suitable concept to rethink the relations of the society and culture at the level of television scripts. Furthermore, reflectiveness or self-relexiveness can be defined as the capacity of a system to reference itself (Mutlu, 1994, p. 176). For this reason, we can say that the television, with its unique story telling methods, is a type of meaning construct. Within the narrative of television programmes, cultural, political and geographical representations are made in original characters, allowing characteristic structures to become visible, referring to the lifestyles that are represented.

Mass communication media have become a sector of the cultural and cultural element industry. The concepts of culture and mass culture have become interchangeable. At the same time, the concept of mass culture is directly related to the concept of a mass society. This concept assumes that Western capitalist societies from the end of the 19th century onwards, have come to consist of atomised individuals and does not take the existence of different social groups and classes into account. Those referring to the concept of mass culture therefore assume that modern societies have a single culture, with the exception of art (Özbek, 2008, p. 9). In the world of today, faced with an increasing number of options, humankind has no other choice than to increase the level of consumption. To remain alive in a consumption based society, consuming at the level required by society has become an obligation. The constant nature of uniformity regulates the relationship with the past. The innovation that separates the phase of mass culture from late liberalism is the exclusion of innovation. This situation determines consumption and also eliminates everything that is yet untried, due to the risks involved (Adorno, 2009, p. $65)$. 
Mass societies commiditise culture with the influence of mass communication media and experience issues related to over- and under-consumption, fears for the future, individuality, loss of meaning and alienation. Mass culture desensitises the masses, taking up their free time and distancing them from social and political life. According to Bauman, who maintains that the culture and society of consumption is a result of the postmodern process; "the society of our forefathers, modern society in its infancy, the industrial age was a society of producers, while at the same deep and basic level, our society is one of consumers" (Baumann, 1999, p. 92). Culture and consumption are intertwined. The materialist side of culture, the material aspect is visible in the culture of consumption.

The concept referred to by the Frankfurt School as the "culture industry" or "mass culture" refers to the capitalist technical elements that keep the individual under control. Horkheimer and Adorno first referenced this concept in their work "the Dialectics of Enlightenment". Adorno explains the usage of the concept as follows: If I am not mistaken, we first used the term culture industry in 1947, in the Dialectics of Enlightenment, the we published together with Horkheimer in Amsterdam. We had used the term "mass culture" in our notes. Later on, in order to avoid comments that would work for the supporters, we decided to use "culture industry" instead of mass culture. They might have considered it a form of modern popular art, and the latter must be distinct from the culture industry. Products the are designed according to the consumption of the masses, that determine the structure of consumption, are produced according to some kind of plan in all sectors. The culture industry deliberately changes the consumers according to its needs." (Adorno, 2003, p. 76). The elements of the culture industry infuses the notion of consumption into human consciousness. The individual caught in the claws of the culture industry is forced to act with an anxiety of becoming part of a whole in each phase of life. The market and sector is constantly forced to produce new products and options to sustain the habit and behaviour of consumption. This means that the product and habit acquired must both change rapidly. The capacity of a system to maintain itself is related to the capacity of the system to renew itself." (Kahraman, 2005, p. $185)$. The requirement for the system to sustain itself is a primary component of maintenance.

Today, we have a choice between hundreds of television and radio channels, styles of games and music, an infinite number of films, magazines and the options offered by the internet. In this chaotic media economy, producers must come up with better content than their competitors in order to fulfil the demands of the consumer and carry both sides to a point of mutual gain." (Dan, 2010, p. 56). The television brings many functions together simultaneously and serves the most significant two goals. On one hand, the television serves as a passtime for individuals to use in their free time, outside of hours reserved for work and sleep. On the other hand, the television brings a certain culture to all, fulfilling the function of cultural transmission and degenerating the culture.

In this context, television programmes, compared with other cultural products and mass communication media, are consumed by a larger number of people. As the communication industry becomes more dominant in the lives of individuals, becoming an element of persuasion, the simulacra and simulated lives distance the individual from the life she belongs to, preventing her from thinking about reality. The character, life, relationships and social circle individual are affected by all of the components involved in the communication process. This results in the differentiation of the behaviour of avoidance of internal anxieties and the patterns perception of of daily life rhythms. At the same time, firstly and most significantly the sceptical nature of the individual and then the undesirable behaviour paterns, attitudes and philosophies are eroded. In time this change and transformation at the individual level leads to change in significant areas such as culture, politics and society, facilitating transformation into the desired types and models. Adoption of transformation brings a debate on the notions of mass society, cultural changes and popular culture. The constructs that are presented in time based on a perceived demand by the masses that are homogenised, lead into standardisation and cultural transformations, turning into carbon copies except from a few small details, form the cycle of consumable elements. The constructs from which the notions of culture and intercultural communication stem from, form one of the main areas of discussion between world governments, including Turkey. Although the debates are ongoing, we see that the strength to stand strong against change and transformation has not yet been gathered. We cannot deny the fact that media organizations, benefiting from the power of globalisation, have established a hegemony within our lives. 


\section{THE SERIES "FAREWELL TO RUMELIA" AND THE CULTURE OF COEXISTENCE IN THE BALKANS}

"Our story is that of a poor father and his daughters, living in Macedonia under Ottoman rule in the 1900's. Sütçü Ramiz and his family live in the Pürşıçan village of Bitola. It is the beginning of the end for the Ottomans. The internal strife has begun in the Balkans. The separatists in Macedonia have become more active and are signalling that greater things will happen in the near future. On one side, the Unitarians are working against the Sultan Abdülhamit, opposing the Ottoman government. The world and therefore Macedonia, are changing rapidly. Ramiz loves the Rumelian lands he grew up in, as well as the people who have lived together in these lands for years. Sütçü Ramiz is yet distanced from worldly problems. Ramiz earns his living and feeds his wife and five daughters with a few buckets of milk that his cow gives him and his biggest wish in life is to marry off his dear daughters, saving them from poverty." (Farewell to Rumelia, Official Website, www.elvedarumeli.com) Many studies have been carried out in the past in regard to the cultural functions of the television. Mass communication media and specifically television programmes, have overcome regional, religious, ethnic, economic, political, social and geographical divides, to unconditionally bind individuals from every age group and status, since the invention of the television set. The television serves to homogenise culture through constructs of common experiences. The media brings individuals, communities, nations and masses closer together through this mission of homogenisation. At the same time, the media shapes life around a common cultural axis. Today culture and cultural values can be delivered simultaneously, to the farthest corners of the world. Cultural codes that cause individuals to react in a standardised way and the fact that these codes are dominant throughout societies, cause different doors to open beyond our wildest dreams, transcending the boundaries of written culture.

The series Farewell to Rumelia is a successful example of story telling, being based on the dominance of Turkish culture and Turkish language in the Balkans after the Ottoman conquest and the culture of coexistence between the peoples of different ethnic backgrounds living in region within the common cultural structure. Through history, the Balkan re- gion has been the scene of scattered settlements by a number of different peoples, allowing the cultural fusion, creation of a common culture and the raising of a common awareness between the peoples. In the Balkans, the stepchild of the Ottoman Empire, we are able to observe many similar practices in social life as well as shared cultural elements. From this notion, we can say that during the rule of the Ottoman Empire in the Balkans, Islam had also become more widespread, while the concepts of Muslim and Turk had come to refer to a common situation. In short, the concepts of "Muslim" and "Turk" came to mean the same thing.

The existence of common cultural structures in the Balkans, formed by the dominance of the Ottoman Empire from the 14th century onwards, as well as the existence of common religious elements weakened the Ottoman Empire, leading to the withdrawal from the Balkans and ultimately, migration to the Republic of Turkey, facilitating the enculturation process of the peoples remaining in the Balkans. The level of relationships between the Evlad-1 Fatihan (descendants of the conquerors) remaining in the Balkans with peoples of other ethnic backgrounds, affected the perceptions of the groups of each other, as well as their social distance. The social distance, from the perspective of the culture of coexistence, requires further measurement and analysis. Living with differences, in spatial and temporal unity and the increase in perceptive awareness, determines the level of social distance and social relationships. On one hand, perceptions of difference shape the relationships between individuals while on the other hand, is interrelated with the images, symbols and metaphors that their own culture that they belong to, have adopted or have grown up in assigns to the other.

Communities that share the same region but have adopted different beliefs and ideas must internalise that different ways of life may exist, in order to form sound communicative relationships. For the maintenance of the system, instead of a competitive environments, constructs based on mutual dialogue, preventing conflicts and facilitating and supporting coexistence are required. The continuation of these constructs is only possible with structures minimising disagreements and a discourse of coexistence, supporting and adopting a doctrine of multiculturalism. With the concept of multiculturalism we refer to cultural pluralism. Cultural pluralism or multiculturalism indicates a society in which different cultures exist. 
At the basic level, multiculturalism may be defined as the right of each individual to have her own cultural inheritance. Multicultural societies may only exist if a culture does not see itself as superior to the other, if that which is different is not marginalised and if a specific political discourse of ideology is not overly dominant or perceived as ideal. The strong belief that a common lifecycle is possible can be ensured with a strong alliance and common feelings of belonging and respect to the right of each individual to her own cultural inheritance. Multiculturalism is a notion that has emerged as an opposite of discrimination and prejudice, requiring the existence of negotiatory dialogue and the discourse of a world society. Communication arguments, as a basic and inherent component of culture and a complimentary component that permeates the entirety of culture, are high significant. According to many, multiculturalism is a conundrum, a crossroads between common living conditions and constructs of different elements.

Serials are weekly periodical pieces with a high viewer potential that have been broadcasted on Turkish television stations since TRT began broadcasting. The television allows for serials to be broadcasted in instalments and these serials have repetitive and continuous characteristics. Serials are based on scenarios designed to ensure continuity, use basic narrative and many visual techniques to describe a specific situation and the arc of many characters and are produced using thematic materials. The series Farewell to Rumelia is set in Macedonia, when the Balkans were under Ottoman rule in the 1900's and focuses on the struggles of Sütçü Ramiz, a milk seller and his family living in the village of Pürsıçan. The series reflects the conditions of the period, describing the ethnic and religious structure of Macedonia, the elevated competition between the communities, the emergence of various problems and the struggles of groups that had adopted the discource of coexistence for many centuries. As the scenario reflects the multiculturalism in Macedonia, it is one of the best examples of the culture of coexistence between the Bulgarians, Greeks, Serbs, Croats, Bosniaks, Turkey, Romany, Albanians, Romanians and other ethnic backgrounds forming closely related groups. The protagonist of the series, Sütçü Ramiz pushes his wheelbarrow and he narrates information concerniğng the social and ethnic life of Ottoman Macedonia while selling his milk. The simplest explanation of the series Farewell to Rumelia, describ- ing the culture of coexistance, is given by the protagonist Sütçü Ramiz as follows: "This is our town, Pürsıçan. And this is out village, Feveran. I don't know who chose these names or why. There might be stories, ask someone else. Turks, Albanians, Bulgarians, Greeks and Macedonians... we live here like brothers. No one will chase another's chickens; no one will give each other an evil eye. This is how it is. Our girls, our daughters, our sons grow up together. Everyone lives their own ways, traditions and customs. Customs and traditions are important. They tell us where we come from, where we go to. How we live, how we die, our traditions tell us. That's just the way it is."

In the series Farewell to Rumelia, the following scripts give the best idea about the structures supporting multiculturalism, mutual dialogue and coexistence instead of conflict and competition;

Sütçü Ramiz visits his Christian customers and while giving them milk, he wishes them a happy Easter.

-'Happy Easter Master Peter. Happy Easter Madame Elene."

-"Holy Ramadan to you too Brother Ramiz."

The signboard in Cabbar's butcher shop is written in Turkish on top and Macedonian on the bottom.

At night time Sütçü Ramiz and Hasan the Tailor put on a Karagöz puppet show for families with children, some of them coming from different ethnic backgrounds.

In the city, we see people in Western dress and Muslims together.

In many episodes, we hear sincere conversations between Master Stefan and Cabbar the Butcher. Furthermore, the Priest and Imam sit at the same table in the cafe. The Priest and Imam express their sadness that Ramiz's daughter was wounded. The wish that she would get well. During the fight between Hasan and Cabbar, Cabbar hides behind the Priest and the Imam.

Hasan: Don't hide behind the holy men. The Priest and Imam try to persuade Hasan.

Sütçü Ramiz speaks Bulgarian to his donkey Kamuran (Kamuş). He talks to the donkey in Bulgarian, asking his health. However, the donkey has a Turkish name, but he addresses him in Bulgarian, as the donkey was bought from an old Bulgarian as a young foal.

When the Master Vet gets ill, Sütçü Ramiz thinks that he will die, and starts praying with a Besmele. Sütçü Ramiz offers the Master Vet care from his daughters until he gets better. 
Ramiz says the following to his wife about the sick vet: Tomorrow make some soup and take it to them. They are our neighbours, let's do a good deed.

Fatma: You are right dear husband, it is Holy Ramadani Neighbours are closer than brothers.

The Balkans were ruled by the Helenic states, then by the Roman and Byzantine Empires and finally the Ottoman Empire for nearly 550 years. During the Ottoman period, the Balkans enjoyed one of the most consistent periods in its history with the superior administrative qualities, tolerance, justice and consistent government of the Turks. (İnalckk, 1993, p. 29) The social structure shaped by Ottoman rule in the Balkans, led to the emergence of an Ottoman identity as an identity encompassing the entire region, in turn leading to interactions with the other ethnic identities in the Balkans. The Ottomans made no attempts to Turkify or assimilate any of their subjects. Any Turkification due to acceptance of Islam was optional. The Ottomans allowed religious, cultural and linguistic freedom to each of the major religious groups (Orthodox, Armenian, Jewish). (Karpat, 2010, p. 45) The Balkans existed as a political instrument for implementers of political projects throughout history, however the autonomy offered allowed the ethnic groups in the Balkans to enjoy their most fruitful period. As the Ottoman Empire lost hold on its Balkan lands, the great powers disseminated the new ideologies among the Balkan nations, causing nationalism to spread. The weakening of the Ottomans accelerated the process of disintegration and the trend towards establishing new states and modern nations.

The dialogue reflecting the rise of nationalism and the process of disintegration in Farewell to Rumelia best describes the surprise, helplessness and anxiety of the peoples who had coexisted for centuries.

The Bulgarians have abducted the Master Vet at gunpoint to treat Dimitri and are trying to persuade him to do so. The Master Vet asks Ivan his age.

Ivan: I am 24

Vet: I am 75 Your grandfather was my friedn. Master Hac1 Musa, the Ironmonger Todaris and Barber Mahmut, we were all friends, we had no problems. Do you not understand? When the French, the English and the Russian started to pry into Ottoman affairs, that's when we fell on each other. The Ottoman state is weak. But I waste my breath, you don't understand what I say. Because you are young you have no room inside you for love, you only have hate in your eyes... Supporter of the Gangs Trader Petrus: The situation is dire in Istanbul. They are marching on the Ottomans from four directions. Macedonia is a powder keg...
Dimitri, these lands will be divided and there will be chaos...

A conversation in the cafe:

Stefan: They burned the villages. They shot a tobacco planter.

Cabbar: Oh goodness, what do they want? What do they want?

Imam: This is sinful and wrong, this shouldn't happen on the eve of Bayram.

Stefan: They have a problem with the Ottomans. They take it out on innocent villagers.

Priest: This cannot go on, today Uçan, tomorrow it will be Pürsıçan. It's chaos good masters. A solution must be found quickly...

Gang members who see and follow Zarife and Alex:

Gang member: Where have you been Macedonian child?

Alex: I don't owe you an explanation Bulgarian child. Gang member: It's not right for a Muslim girl to be with a Macedonian boy.

Zarife, who has come to meet Alex: I wasn't going to come... But I did

Alex: Why should you not come?

Zarife: I am afraid Alex, what if someone sees us? I am Muslim, you are Christian. You know this doesn't happen here.

Alex: I know I am Christian and you Muslim. What can I do, I can't make my heart listen.

The come to the decision that their love will not be accepted and they give up. They decide to become friends.

Ramiz's family is clearing the wedding area after a shootout when 3 Bulgarian neighbour arrive.

Bulgarian Neighbours: We are sorry Sister Fatma...

Fatma: Did you see what your boys did?

Bulgarian Neighbours: We heard, we are sorry and we want to help.

Fatma: I don't need your help thank you.

Bulgarian Neighbours: Sister Fatma, we are not to blame...

Fatma: You're right, it's not your fault. It's not our fault, but there is fault, whose it is God knows... Fatma accepts their help.

To explain the primary component of coexistence we must use social dialectic to examine the individual processes to understand how existing perceptions and differences in the society transform into significant otherness. The culture of coexistence may only develop through an understanding in the sociological context of identities in the environment attributed as the "other", their dreams, struggles, anxieties, desires, customs; in short, their lifestyles. 
To develop an ethical approach to the different lifestyle of another person of group that is conflicting with that of the group defined as "us", instead of irrational definitions, we must be able to understand "them" through their own perspective. (Fay, 2001, p. 131) Experiencing differences is the existence of different lifestyles in the same geographical area with mutual relationships for groups who are forced to coexist, sharing the same spatial and temporal conditions. To experience the other, form a relationship, develop intra-group consistency and decrease social distance to the other groups, a culture of tolerance must be developed. Multicultural societies owe their existence to disallowing the perception of supremacy of one group over another, preventing the marginalisation of that which is different, and strong connections and common lifecycles. This is possible only with a sense of common life, common belonging and respect to the right of the individual to her own cultural inheritance.

\section{CONCLUSION}

It is an irrefutable truth that the media has assummed functions such as cultural, social and political information and entertainment, constructing and presenting social relality, ensuring cultural continuity and leading cultural change, becoming an inseparable part of the daily lives of individuals. With the power derived from globalisation and armed directly or indirectly with mass communication arguments, the media uses cultural programs to shape cultural development and constructs to exercise the power of leading this development. One of the most effective mass communication media today, the television, brings together images and sound to reflect culture and cultural components most effectively. It is undeniable that mass communication media affect societies. However, it would not be truthful to say that the media is the only influence behind the formulation of culture and the orientation of society. The media has an undeniable role in initiating and shaping cultural change through messages given to viewing masses. From this argument, we can say that together with the phenomenon of globalisation, these mass communication media, known as media culture today, hold the power to rule and shape the masses.

The power of the media to influence culture and the power of culture to influence the media illustrates the nature of the grift relationship between media and culture. The mass communication media that samples the interactive process most strikingly, is the television. We cannot think of the subject matter of television programmes and series separately from the society or social reality. As the scenarios of television series may be based on social elements and cultural structures, while screenwriters or others writing the story may use the scenarios to present different points of view to the society. In this way, the media carries out the function of homogenising the community and also describes the culture of coexistence, bringing together the masses to create common living areas.

The number and activities of private television channels in Turkey as well as the number of domestic series has been increasing since 1995 . The content of series produced for Turkish television today take into account the wishes of the viewers and we can say that the content consists of national themes.

Considering the common historical and cultural past described in Farewell to Rumelia, the story of Sütçü Ramiz, living in the village of Pürsıçan in the 1900's, in Macedonia under Ottoman rule is a story of the political and social structures of the era. Farewell to Rumelia uses environments frequently used in other Turkish television series such as houses, neighbourhoods and villages to evoke the social images of neighbour relationships and the family institution while religious buildings such as mosques, churches, monasteries and madrasas to describe the culture of coexistence.

We can say that in the Balkans, people from different ethnic backgrounds with different cultural elements and different beliefs can come together under common cultural contexts, forming the conditions for coexistence. Farewell to Rumelia, one of the elite examples of inter-cultural communication, reminds Turkish viewers of the existence of the Evlad-1 Fatihan, who have lived in the Balkans for centuries since Ottoman times. It would not be wrong to say that the series is one of the most successful examples of meaning transference in the name of the culture of coexistence. The unique features of the series are the perception of unity with other individuals through communication for individual who are social and/or socialising. In Farewell to Rumelia, the emphasis on a common history in the historical context, the myth of race, culture and coexistence upon the same piece of land and government relations are all very interesting. We must underline that the series is important to understand the history of the Balkans, the most significant example of multiculturalism and coexistence in history, to understand the cycle of social distance between different ethnic groups Considering Balkan history together with Turkish history would be enlightening in the attempt to understand the lives and social structures. 


\section{REFERENCES}

Adorno, T. W. (2009). 'Kültür Endüstrisi: Kültür Yönetimi", Çev: Nihat Ülner-Mustafa Tüzel-Elçin Gen, İstanbul: İletişim Yayınları.

Adorno, T. W. (2003). 'Kültür Endüstrisini Yeniden Düşünürken", İstanbul: Cogito, S. 36.

'Balkanlardaki Gelişmeler ve Türkiye'ye Etkileri ile Balkanlar”. (1999). İstanbul, Türkiye: Otoyol Projesi, HAK Yayınları. Bauman, Z. (1999). "Küreselleşme: Toplumsal Sonuçları", Çev: Abdullah Yılmaz, 1. Basım., İstanbul: Ayrıntı Yayınları.

Buran A. \& Yüksel, Ç. B. (2012). "Türkiye Diller ve Etnik Gruplar", Ankara: Akçağ Basım.

Dan, Laughey. (2010). 'Medya Çalışmalarl: 'Teoriler ve Yaklaşımlar", 1.Baskı. İstanbul: Kalkedon Yayıncılık.

Davutoğlu, A. (2001). 'Stratejik Derinlik: Türkiye'nin Uluslararası Koпити”, Stratejik Araştırmalar 1, Küre Yayınları, İstanbul.

Eker, S , (2006). 'Bosna'da Etno-Linguiskik Yapı ve Türk Dili ve Kültürü Üzerine”, www.millifolklor.com, , Erişim Tarihi: 23.02.2013.

Elveda Rumeli Dizisi, Resmi Web Sayfası, http://www.elvedarumeli.com/dizihakkinda.html, Erişim Tarihi: 23.02.2013.

Erkal, Mustafa. E. ( 2005). 'Küreselleşme, Etniklik ve Çokkültürlülük”, İstanbul: Derin Yayınları.

Fay, B. (2001). "Çağdaş Sosyal Bilimler Felsefesi", Çeviren: İsmail Türkmen, İstanbul: Ayrıntı Yayınları.

İnalc1k, H. (1993). “Türkler ve Balkanlar”, Balkanlar, İstanbul:
Ortadoğu ve Balkan İncelemeleri Vakfi Yayınları.

Jelavich, B. (2006). "Balkan Tarihi, Cilt:1 (18. ve 19. Yüzylllar)", Çev: İhsan DURDU-Haşim Koç GÜLÇiN, İstanbul: Küre Yayınları.

Jezernik, B. (2006). "Vahşi Avrupa; Batı'da Balkan İmajı", Çev: Haşim Koç, İstanbul: Küre Yayınları.

Kahraman, H. B. (2005). "Sanatsal Gerçeklikler, Olgular ve Öteleri”, 3. Basım, İstanbu:l Agora Kitaplığı.

Karpat, Kemal H. (2010). 'Osmanlı'dan Günümüze Etnik Yapılanma ve Göçler", İstanbul: Timaş Yayınları.

Kavalalı, M. 'Avrupa Birliğinin Genişleme Süreci: AB'nin Merkezi Doğu Avrupa ve Batı Balkan Ülkeleri İle İlişkileri", Devlet Planlama Teşkilatı Müsteşarlığı (AB İle İlişkiler Genel Müdürlüğ̈̈ ), Ekim 2005, s. 37, http://ekutup.dpt.gov.tr/, Erişim Tarihi: 23.02.2013.

Mutlu, E., (1994). "'́letișim Sözlüğü",, Ankara: Ark Yayınevi.

Özbek, M. (2008). 'Popüler Kültür ve Orhan Gencebay Arabeski", İstanbul: İletişim Yayınları.

Özkürkçü, E. G. (1998). 'Balkanların Coğrafi Копити, Bölgenin Jeopolitik, Jeostratejik ve Jeoekonomik Özelliklerinin, Bölgedeki Güç ve Rekabet Mücadelelerine Olan Etkileri", Balkanlar ve Türkiye'nin Bölgeye Yönelik Politikaları Sempozyumu, Hak Yayınları.

Palairet, M. (2000). 'Balkan Ekonomileri 1800-1914 Kalkinmasız Evrim”, Çev: Ayşe Edirne, İstanbul: Sabancı Üniversitesi Yayınevi.

Postman, N. (1994). 'Televizyon: Öldüren Ë̆lence Gösteri Çă̆ında Kamusal Söylem”, Çeviren: Osman Akınhay, İstanbul: Ayrıntı Yayınları. 